\title{
Innovation, institutional ownership and financial constraints
}

\author{
Jan Philip Schain ${ }^{1} \cdot$ Joel Stiebale ${ }^{1,2} \mathbb{E}$
}

Received: 3 December 2019 / Accepted: 2 July 2020 / Published online: 18 July 2020

(c) The Author(s) 2020

\begin{abstract}
We analyze the relationship between institutional investors, innovation and financing constraints. Using the same dataset as Aghion et al. (Am Econ Rev 103(1):277-304, 2013), we find that the effect of institutional ownership on innovation is concentrated in industries with high dependence on external finance and among firms which are a priori likely to be financially constrained. The complementarity between institutional ownership and competition, predicted by the original paper's theory where institutional investors increase innovation through reducing career risks, disappears once this heterogeneity is taken into account. We also provide evidence that the sensitivity of R\&D investment to internal funds decreases with institutional ownership.
\end{abstract}

JEL Classification G23 · G32 - L25 · M10 · O31 · O34

\section{Introduction}

The growing presence of institutional ownership has led to a controversial policy debate. A particular concern is that institutional investors have a focus on short-term performance which is detrimental to long-run investment such as research and development (R\&D) and innovation. In an important and widely cited paper, Aghion et al.

\footnotetext{
We are grateful to seminar participants in Düsseldorf, Toulouse and Lenzerheide (Switzerland) for helpful comments and suggestions. We would also like to thank Andrea Ciani and Dirk Czarnitzki for helpful discussion.

$凶$ Joel Stiebale

stiebale@dice.hhu.de

Jan Philip Schain

schain@dice.hhu.de

1 Düsseldorf Institute for Competition Economics (DICE), University of Düsseldorf, Düsseldorf, Germany

2 GEP, University of Nottingham, Nottingham, UK
} 
(2013), henceforth AVRZ, estimate a positive effect of institutional ownership on innovation.

They explain this effect by a career concerns model which is related to Holmström (1982). In this model, managers with ex ante unknown ability can choose non-innovative activity, which yields a certain return independent of managerial ability, and innovation which implies an uncertain outcome that is positively related to management quality and negatively related to product market competition due to a risk of imitation. As the market cannot separate ability from luck, managers might be reluctant to innovate due to the risk of being fired in the case of an adverse innovation outcome. Due to monitoring, institutional investors can identify and reward managerial ability. This insures able managers against unlucky innovation outcomes which the market would interpret as a negative signal of their ability and induces them to innovate.

This theory implies that institutional ownership and product market competition are complements since competition increases the probability of innovation failure. ${ }^{1}$ As argued by AVRZ, the channels by which institutions affect innovation have important implications. According to the career concerns model, policy measures which lead to less outside board membership and higher board representation of insiders such as institutional owners are expected to increase innovation.

In this paper, we test the hypothesis that institutional investors induce innovation by alleviating financial constraints.

Since $R \& D$ is typically associated with lower collateral value but higher riskiness and asymmetric information problems compared to tangible investment, financial constraints play and important role for the financing of innovation (e.g., Brown et al. 2012; Hottenrott and Peters 2012; Stiglitz and Weiss 1981). This suggests that institutional owners may alleviate asymmetric information problems in credit markets and improve access to finance. Firms may benefit from institutional ownership directly via lower financing costs or indirectly because institutional investors' monitoring activities and financial expertise may act as a signal for creditors that their funds are used productively (Boucly et al. 2011). For this purpose, we estimate heterogeneous effects of institutional ownership on innovation among firms which are likely to face different degrees of financial constraints.

Our results indicate that positive effects of institutional investors on innovation are concentrated in industries with high degrees of dependence on external finance, measured according to Rajan and Zingales (1998), and among firms with initially low credit ratings for which financial constraints arguably play an important role. ${ }^{2}$ Further, we find that the complementarity between competition and institutional ownership estimated by AVRZ vanishes after financial dependence, and its interaction with institutional ownership, is controlled for. Hence, we argue that the positive association between institutions and innovation is likely to stem from access to finance rather than an insurance against innovation failure. Our results are robust to using instrumental variables (IV) and a variety of other robustness checks. We also con-

\footnotetext{
1 See Belloc (2012) for an overview of related literature and Bena et al. (2017) for a recent contribution.

2 See Carreira and Silva (2010) for an overview of stylized facts related to financing constraints.
} 
duct various additional tests which are consistent with institutional owners alleviating financial constraints.

The rest of this paper is organized as follows. Section 2 describes the econometric specification. Results of the empirical analysis are presented in Sect. 3 and Sect. 4 concludes.

\section{Empirical analysis}

For our empirical analysis, we use the same dataset as AVRZ and build on their empirical model. ${ }^{3}$ Our starting point is AVRZ's baseline specification where the conditional expectation of innovation is modeled as:

$$
E\left(\operatorname{CITES}_{\mathrm{it}} \mid x_{\mathrm{it}}\right)=\exp \left(\alpha \operatorname{INSTIT}_{\mathrm{it}}+\beta \mathbf{x}_{\mathrm{it}}+\eta_{i}+\tau_{t}\right)
$$

The outcome variable, CITES $_{\text {it }}$, is computed from the number of granted patents filed by firm $i$ in time period $t$, which are weighted by the number of forward citations to account for heterogeneity in the importance of patents. INSTIT it $_{\text {measures the }}$ proportion of equity owned by institutional investors, $\mathbf{x}_{\mathbf{i t}}$ contains control variables including sales, capital intensity, R\&D stock and industry dummies, $\tau_{t}$ denotes time dummies. Firm fixed effects $\eta_{i}$ are introduced into the model using the pre-sample mean of citation-weighted patents as suggested by Blundell et al. (1999). Following AVRZ, the main specification is estimated as a Poisson model, but we also consider alternatives including a negative binomial model.

We extend Eq. 1 to test for heterogeneous effects of institutional ownership on innovation according to an industry's degree of financial dependence using a measure developed by Rajan and Zingales (1998):

$$
E\left(\operatorname{CITES}_{\mathrm{it}} \mid x_{\mathrm{it}}\right)=\exp \left(\alpha_{0} \operatorname{INSTIT}_{\mathrm{it}}+\alpha_{1} \operatorname{INSTIT}_{\mathrm{it}} \times \operatorname{FIN}_{j(i)}+\beta \mathbf{x}_{\mathrm{it}}+\eta_{i}+\tau_{t}\right)
$$

where $\operatorname{FIN}_{j(i)}$ measures financial dependence of industry $j .{ }^{4}$ The interaction term $\left(\right.$ INSTIT $_{\text {it }} \times$ FIN $\left._{j(i)}\right)$ accounts for heterogeneous effects of institutional investors across industries with varying degrees of dependence on external finance. If institutional investors induce innovation via an alleviation of financing constraints, we expect the interaction term to be positive. Note that the effect of industry-level financial dependence independent of ownership is absorbed by industry dummies and does therefore not enter as a separate regressor. We further extend Eqs. 1 and 2 to analyze how the effect of institutional investors varies with competition as in AVRZ and to

\footnotetext{
3 The dataset contains information on 800 firms and 6178 firm-years and is compiled from the databases Compustat, Compact Disclosure and the NBER Patent Database. The data are available at https://www. aeaweb.org/articles.php?doi=10.1257/aer.103.1.277. We provide descriptive statistics in Tables A1 and A2 in the Online Appendix.

4 The measure is calculated as the median of capital expenditures minus cash flow from operations relative to capital expenditures for 39 different 3-digit industries. A similar empirical strategy is chosen by Boucly et al. (2011) who analyze the relationship between buyouts and firm growth. Among others, Amore et al. (2013) show that firms in industries with high financial dependence benefit most from stock market and banking development.
} 
investigate how this effect changes when we introduce the interaction between institutional investors and financial dependence.

It is likely that firms with low or no credit rating have to pay a higher cost premium for external finance (e.g., Czarnitzki and Hottenrott 2011; Rodano et al. 2016). In an alternative specification, we therefore use Standard and Poor's credit rating as an additional measure to differentiate between firms that are likely to be affected by credit constraints to a different extent. We interact institutional ownership with a dummy variable for firms with high credit rating. If institutional investors induce innovation by alleviating credit constraints, we should see a negative coefficient for this interaction term and a positive coefficient for INSTIT it. To reduce potential endogeneity problems, we use data on credit ratings from the pre-sample period (1988 to 1990).

\section{Results}

\subsection{Basic results}

In the Online Appendix, Sect. 2, we replicate the main results of AVRZ. Their main results show that across various specifications, institutional ownerships are positively associated with innovation and that this association is driven by industries with high levels of competition. ${ }^{5}$

Table 1 shows our main results. Column (1) contains estimates of Eq. 2 using a Poisson model that accounts for unobserved firm heterogeneity and control variables.

The coefficient of institutional ownership in column (1) indicates that an increase in institutional ownership by $1 \%$ point (pp) increases innovation output by about $0.28 \%$ when financial dependence takes a value of zero. This corresponds to an industry where the median firm's capital expenditures are equal to its operating cash flow. The interaction term between institutional ownership and financial dependence is highly significant and positive, indicating a higher association between institutional investors and innovation in industries that are more reliant on external finance. Starting from a situation where financial dependence takes a value of 0 , an increase in financial dependence by one standard deviation raises the predicted effect of an additional pp of institutional ownership from approximately $0.28 \%$ to $0.56 \%$. Consistent with the predictions of the career concerns model, results in AVRZ indicate that institutional investors have a higher impact on innovation in industries with high level of competition. We argue that the main channel that drives this result is related to financial constraints. When competition is high, firms have limited internal financial resources due to low profits and have to rely more on external capital. Since the career concerns model predicts complementarity between institutional ownership and competition for reasons that are unrelated to financial constraints, we believe that it is important to control for financial dependence when this interaction term is estimated.

In column (2), we add an interaction term between competition, measured as 1 minus the average of the Lerner index at the industry level, and institutional ownership.

\footnotetext{
5 Note that there are minor differences between our coefficient estimates and those by AVRZ as we lose 30 observations by limiting the sample to industries for which financial dependence can be computed. However, this leaves the conclusions unchanged.
} 


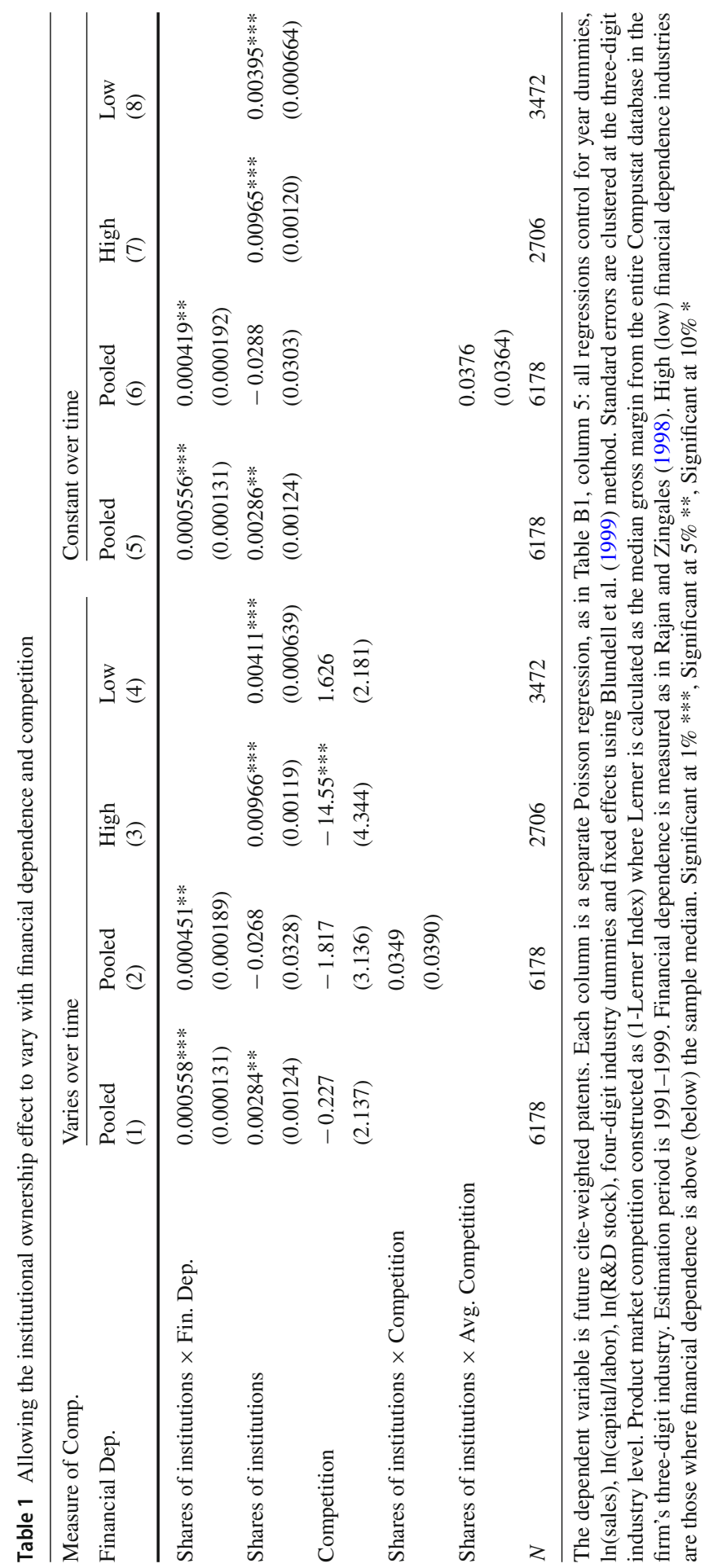


In contrast to AVRZ, this interaction term is statistically insignificant. ${ }^{6}$ At the same time, the interaction of institutional ownership with financial dependence is almost unchanged compared to the results in column (1) and remains statistically significant at the 5 percent level. The result that the interaction term between institutional ownership and competition is not robust to controlling for financial dependence might be due financial constraints being more severe in competitive industries. ${ }^{7}$

In columns (3) and (4), we split the sample between industries with a financial dependence measure below and above the median. Consistent with the importance of financial factors, the coefficient for institutional ownership is more than twice as large in the high-dependence subsample.

The measure of competition in columns (1) to (4) is based on time-varying values of the Lerner index. However, following AVRZ, we also estimate specifications using a time-invariant measure based on the average over the sample period to reduce endogeneity concerns. Results in columns (5) to (8) indicate that this does not change our conclusions regarding the importance of financial dependence and competition. ${ }^{8}$

Table 2 contains results of regressions using different model specifications and alternative indicators of financial constraints. Columns (1) and (2) show linear fixed effects models where column (2) additionally controls for R\&D stock. Column (3) shows results of a Poisson regression with an interaction term between institutional ownership and $I(A)$, a dummy variable indicating firms with rating "A-" or higher. As expected, the interaction term is negative and highly significant, indicating that institutional investors mainly spur innovation in firms that are likely to be confronted with financial constraints. Results obtained from a negative binomial model are documented in columns (4) and (5) with the credit rating and the continuous financial dependence measure, respectively. One might be concerned about the implicit assumption of a linear effect of financial dependence and the role of potential outliers. To address this concern, we rank industries according to the value of financial dependence in an alternative specification. The industry with the lowest value of financial dependence is assigned rank 1 , and the industry with the highest financial dependence is assigned rank 39. Column (6) shows that the interaction of institutional ownership with this ordinal scale of financial dependence is positive and statistically significant as well. All these robustness checks do not change our conclusion regarding the interaction of institutional investors with financial dependence.

\subsection{Extensions and robustness checks}

In the Online Appendix, we document the results of various extensions and robustness checks which mostly follow AVRZ. First, we show that our results are robust toward controlling for endogeneity using membership of the S\&P 500 index as an instrumental

\footnotetext{
${ }^{6}$ As we show in Appendix B, the coefficient for the interaction between competition and institutional ownership is 0.082 and statistically significant at the $5 \%$ level when financial dependence is not controlled for.

${ }^{7}$ See Galle (2019) for a recent contribution on the relationship between competition and financial constraints.

${ }^{8}$ Note that the effect of competition independent of institutional ownership is absorbed by industry fixed effects in this specification.
} 


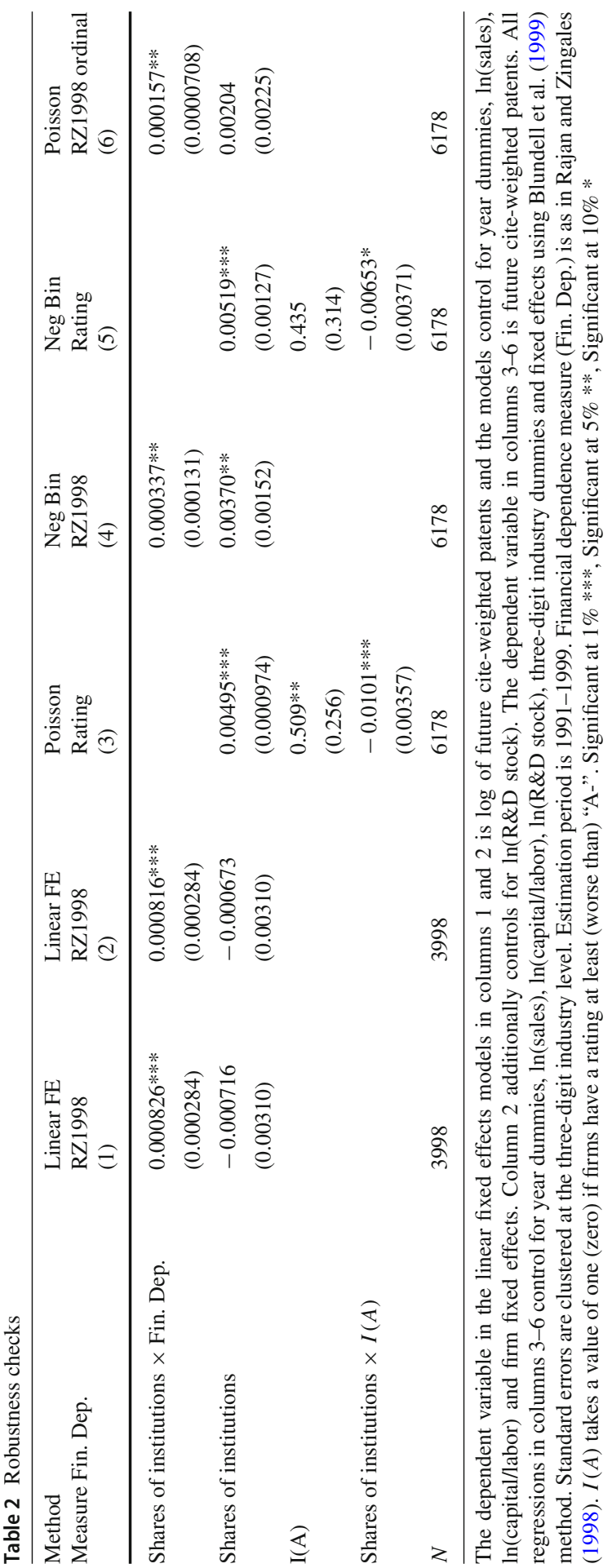


variable and including firm value as an additional control variable. Further, we show that our results are driven by more active institutional investors, while quasi-indexed funds are not significantly associated with innovation, independent of the degree of financial dependence. Since monitoring by active investors can act as a signal for creditors, we believe that these results are consistent with our proposed mechanism.

We also provide evidence on management turnover that is consistent with our proposed mechanism. Following AVRZ, the probability of CEO turnover responds less to changes in profits in firms with high ownership share of institutional investors. However, we show that, again, this effect is driven by industries with financial dependence indicating that this association is driven by financial constraints rather than the career concerns mechanism. Finally, we provide evidence that institutional investors are associated with a lower dependence of $R \& D$ expenditures to the availability of internal funds as an alternative measure of financial constraints.

\section{Conclusion}

This paper builds on recent work by Aghion et al. (2013) who estimate a positive relationship between institutional investors and innovation. They explain this effect by institutional investors' monitoring which allows them to identify and reward managerial ability in risky innovation projects. We test the hypothesis that institutional investors induce innovation by alleviating financial constraints. Our results indicate that institutional investors have a higher impact in industries that are more dependent on external finance and among firms with initially low credit ratings. Once we control for an interaction term between financial dependence and institutional ownership, we find that the impact of institutional investors does not significantly vary with competition which does not support the main prediction of the career concern model of Aghion et al. (2013).

Our results have important policy implications. The career concerns model implies that policy measures that increase board representation of blockholders relative to outsiders may spur innovation. In contrast, the results of our paper indicate that policy measures aiming to induce innovation should facilitate access to external equity in financially dependent industries.

Acknowledgements Open Access funding provided by Projekt DEAL.

Funding No external funding was obtained for this study.

\section{Compliance with ethical standards}

Conflict of interest Jan Philip Schain declares that he has no conflict of interest. Joel Stiebale declares that he has no conflict of interest.

Human and animal rights statement This article does not contain any studies with human participants or animals performed by any of the authors.

Open Access This article is licensed under a Creative Commons Attribution 4.0 International License, which permits use, sharing, adaptation, distribution and reproduction in any medium or format, as long as you give 
appropriate credit to the original author(s) and the source, provide a link to the Creative Commons licence, and indicate if changes were made. The images or other third party material in this article are included in the article's Creative Commons licence, unless indicated otherwise in a credit line to the material. If material is not included in the article's Creative Commons licence and your intended use is not permitted by statutory regulation or exceeds the permitted use, you will need to obtain permission directly from the copyright holder. To view a copy of this licence, visit http://creativecommons.org/licenses/by/4.0/.

\section{References}

Aghion P, Van Reenen J, Zingales L. Innovation and institutional ownership. Am Econ Rev. 2013;103(1):277-304.

Amore MD, Schneider C, Žaldokas A. Credit supply and corporate innovation. J Financ Econ. 2013;109(3):835-55.

Belloc F. Corporate governance and innovation: a survey. J Econ Surv. 2012;26(5):835-64.

Bena J, Ferreira MA, Matos P, Pires P. Are foreign investors locusts? The long-term effects of foreign institutional ownership. J Financ Econ. 2017;126(1):122-46.

Blundell R, Griffith R, Van Reenen J. Market share, market value and innovation in a panel of British manufacturing firms. Rev Econ Stud. 1999;66(3):529-54.

Boucly Q, Sraer D, Thesmar D. Growth LBOs. J Financ Econ. 2011;102(2):432-53.

Brown JR, Martinsson G, Petersen BC. Do financing constraints matter for R\&D? Eur Econ Rev. 2012;56(8):1512-29.

Carreira C, Silva F. No deep pockets: some stylized empirical results on firms' financial constraints. J Econ Surv. 2010;24(4):731-53.

Czarnitzki D, Hottenrott H. Financial constraints: routine versus cutting edge R\&D investment. J Econ Manag Strat. 2011;20(1):121-57.

Galle, S. Competition, financial constraints and misallocation: plant-level evidence from Indian manufacturing. Available at SSRN 3267397; 2019.

Holmström, B. Managerial incentive problems - a dynamic perspective. In: Essays in economics and management in honour of Lars Wahlbeck; 1982, pp. 209-230.

Hottenrott H, Peters B. Innovative capability and financing constraints for innovation: more money, more innovation? Rev Econ Stat. 2012;94(4):1126-42.

Rajan RG, Zingales L. Financial dependence and growth. Am Econ Rev. 1998;88(3):559-86.

Rodano G, Serrano-Velarde N, Tarantino E. Bankruptcy law and bank financing. J Financ Econ. 2016;120:363-82.

Stiglitz JE, Weiss A. Credit rationing in markets with imperfect information. Am Econ Rev. 1981;71(3):393410.

Publisher's Note Springer Nature remains neutral with regard to jurisdictional claims in published maps and institutional affiliations. 